\title{
1
}

\section{Background and Current Status}

\author{
Yushan Liu ${ }^{1}$, Haitham Abu-Rub ${ }^{1}$, Baoming Ge ${ }^{2}$, Frede Blaabjerg ${ }^{3}$, \\ Poh Chiang Loh ${ }^{3}$ and Omar Ellabban ${ }^{1,4}$ \\ ${ }^{1}$ Electrical and Computer Engineering Program, Texas A\&M University at Qatar, \\ Qatar Foundation, Doha, Qatar \\ ${ }^{2}$ Department of Electrical and Computer Engineering, Texas A\&M University, \\ College Station, TX, USA \\ ${ }^{3}$ Department of Energy Technology, Aalborg University, Aalborg East, Denmark \\ ${ }^{4}$ Department of Electrical Machines and Power Engineering, Helwan University, Cairo, Egypt
}

Significant research efforts are underway to develop commercially viable, technically feasible, highly efficient, and highly reliable power converters for renewable energy, electric transportation, and various industrial applications. This chapter presents state-of-the-art knowledge and cutting-edge techniques in various stages of research related to impedance source converters/ inverters, including the concepts, advantages compared to existing technology, classification, current status, and future trends.

\subsection{General Introduction to Electrical Power Generation}

\subsubsection{Energy Systems}

Electric power generation comprises traditional power generation, such as hydroelectric, thermal and nuclear power production, and renewable energy sources, which already has a large penetration joined by photovoltaic (PV) and wind energy [1]. Climatic constraints and large amounts of pollution require us to limit our development and utilization of traditional energy. Renewable energy and energy savings are receiving a greater attention as a sustainable and environmentally friendly alternative. Figure 1.1 shows the the levels of annual global renewable energy in gigawatts $(\mathrm{GW})$, including solar PV, concentrating solar power (CSP), wind, bioenergy, geothermal, ocean, and hydropower [2]. It can be seen that globally installed

Impedance Source Power Electronic Converters, First Edition. Yushan Liu, Haitham Abu-Rub, Baoming Ge, Frede Blaabjerg, Omar Ellabban, and Poh Chiang Loh.

(C) 2016 John Wiley \& Sons, Ltd. Published 2016 by John Wiley \& Sons, Ltd. 


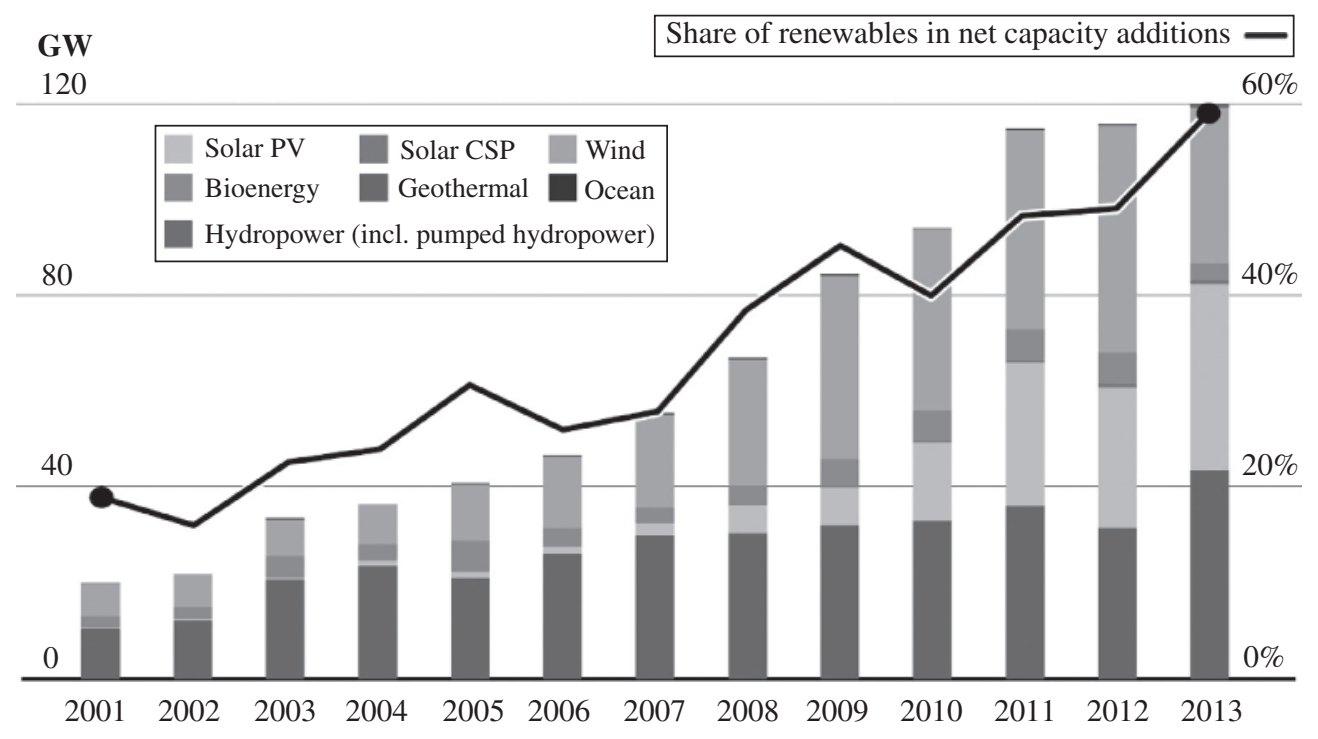

Figure 1.1 Global renewable energy annual changes in gigawatts (2001-2013) [2] (Source: Reproduced with permission of REN21).

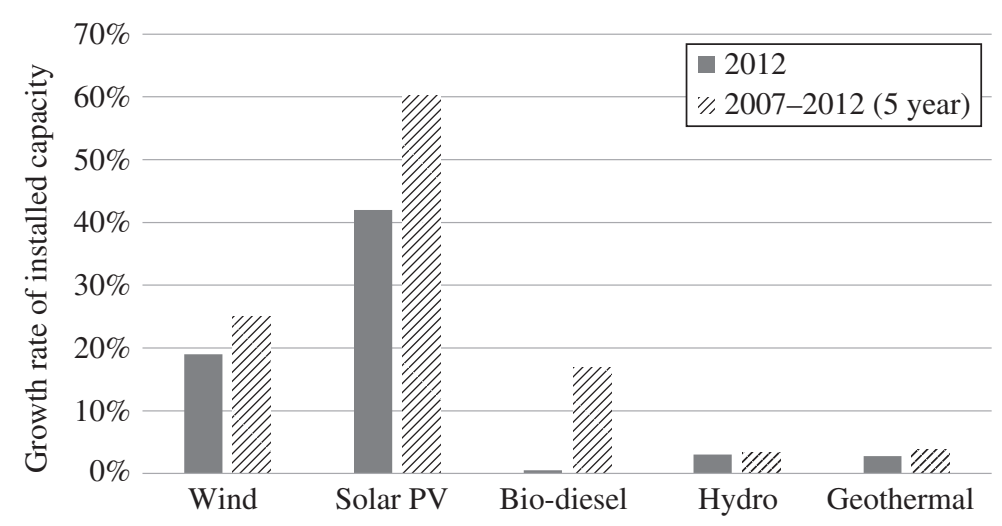

Figure 1.2 Growth rates of installed capacity of different renewable energies [2] (Source: Reproduced with permission of REN21).

renewable energy shows a rapid increase since 2007. To 2013, the share of renewables in net capacity additions has reached 60\%, doubling the share in 2007.

Among global renewable energy sources, wind and solar energy are the leading potential sources of electricity for the 21 st century for several reasons: they utilize an abundant energy source (the sun or wind) and have no emissions. Furthermore, solar power can be easily integrated into buildings, and so on. Figure 1.2 shows the growth rates of installed capacity of different renewable energies in 2012 and in five years from 2007 to 2012 [2]; Figure 1.3(a) and (b) show globally installed wind and PV power capacity to 2014 [3, 4]. The cumulative capacity of wind reached $369.6 \mathrm{GW}$ in 2014, and that of PV in 2014 is $177 \mathrm{GW}$. It can be seen 
(a)

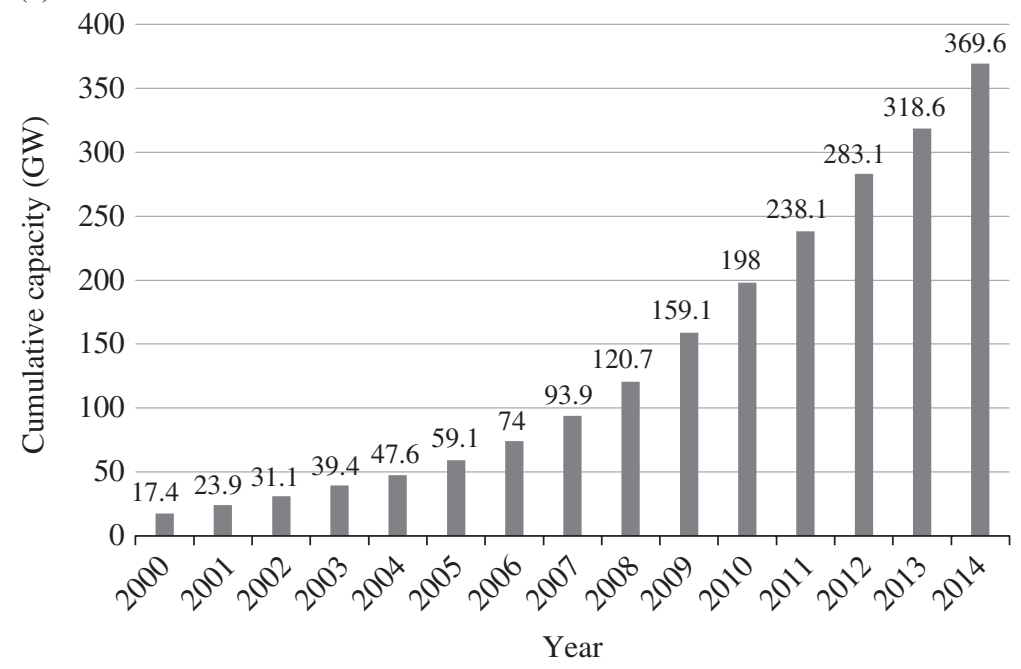

(b)

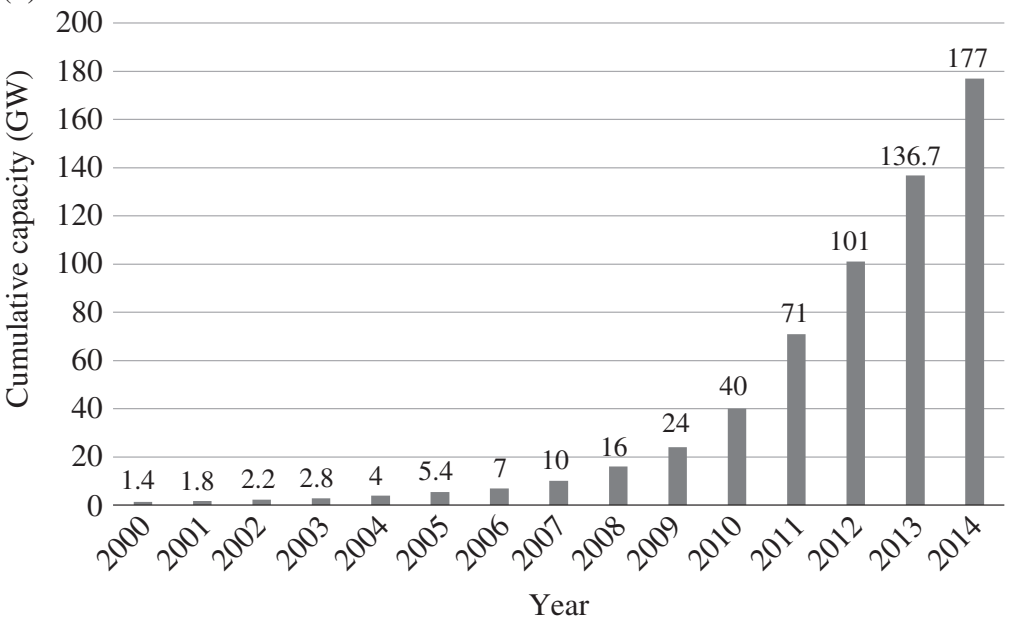

Figure 1.3 Globally installed (a) wind power capacity [3] (Source: Delphi234, https://commons. wikimedia.org/wiki/File:Global_Wind_Power_Cumulative_Capacity.svg. Used under CC0 1.0 Universal Public Domain Dedication https://creativecommons.org/publicdomain/zero/1.0/deed.en) and (b) PV power capacity (to 2014) [4] (Source: Reproduced with permission of IEA Photovoltaic Power System Programme).

that they have had a fast growth rate since 2007. In addition, fuel cells (FCs) have achieved global attention as an alternative power source for hybrid electric vehicles (HEVs). Fuel cell vehicles (FCVs) have generated interests among industrialists, environmentalists, and consumers. An FCV ensures the air quality, with the wide driving range and convenience of a conventional internal combustion engine vehicle.

Nevertheless, power generated by renewable energy sources is intermittent and heavily depends on the environmental conditions. For instance, the power incident on a solar panel, the panel temperature, and the solar panel voltage affect the utilization of solar power generation; 
similarly, wind speed, wind turbine angular speed, and pitch angle are critical to the amount of harvested wind power. They are unpredictable because of the weather and the seasons. The resultant impact of stochastic fluctuations will have a negative effect on the utility grid in grid-connected mode and on loads in standalone mode. Moreover, power consumption also presents its own characteristics of seasonal and human living habits. In spring and autumn, there are relatively more fine days with a lot of renewable energy compared with the other seasons. These seasons also have good weather; thus, electric loads such as air conditioners may be used less often. Consequently, increased generation from renewable energy power systems and reduced loads cause a voltage rise on the power distribution line. At weekends, during which the systems continue to produce the same amount of power and industrial loads are lower, the grid voltage and frequency could easily become high. Overvoltage may exceed the upper tolerance limit at the point of common coupling; usually grid overvoltage protection will regulate the output power of the renewable energy system if the AC voltage exceeds the control range. Fuel cells prefer to be operated at constant power to prolong their lifetime and it is also more efficient in this way. However, the traction power of a vehicle is ever-changing.

An energy storage unit installed in a renewable energy system may be used to compensate for the insufficient energy through charging and discharging the energy storage unit, so that renewable energy power systems can become more reliable by acquiring the possibility to cope with some important auxiliary services. Similarly, to balance the difference and also to handle regenerative energy, a battery is often used as an energy storage device in FCVs. Basically, the main source of the vehicle's power is the FC; the secondary power source is the battery, which stores excess energy from the FC, and from regenerative braking [5].

Efficient energy transfer and high reliability of power electronics, involved in the interface between the energy sources and the grid or loads, are essential for converting the fluctuating powers into suitable voltage and frequency AC power [6]. According to the configurations of PV panels between power converters, PV power systems are categorized into AC-module, string, multi-string, and central inverter-based topologies, as shown in Figure 1.4 [6-8]. Figure 1.5 shows wind power generation systems based on induction/synchronous generators (I/SG) or doubly fed induction generators (DFIG) $[9,10]$. To maximize the energy production

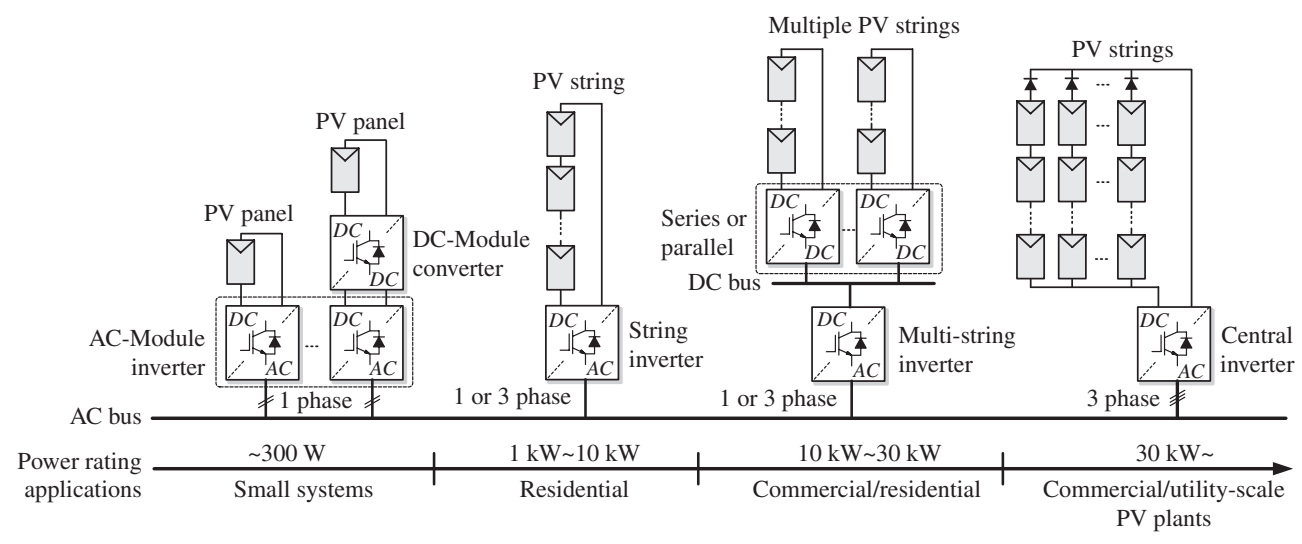

Figure 1.4 PV power systems categorized by configurations of PV panels between power converters (Source: Kjaer 2005 [8]. Reproduced with permission of IEEE). 
(a)

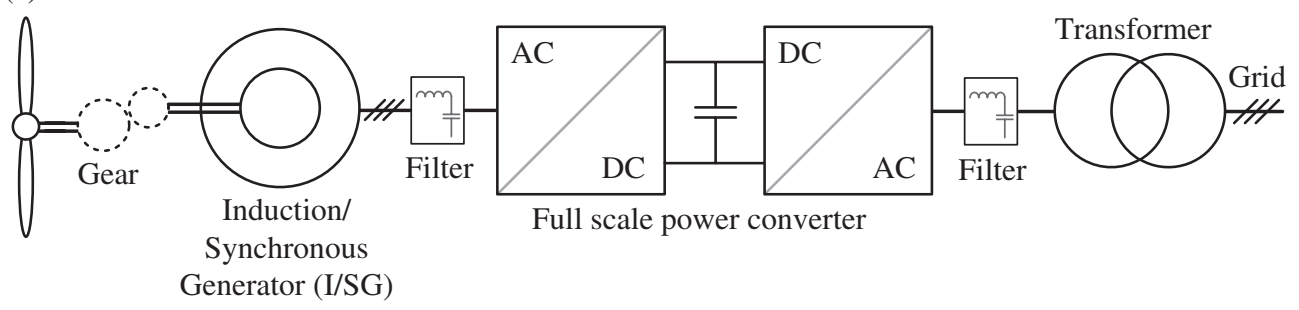

(b)

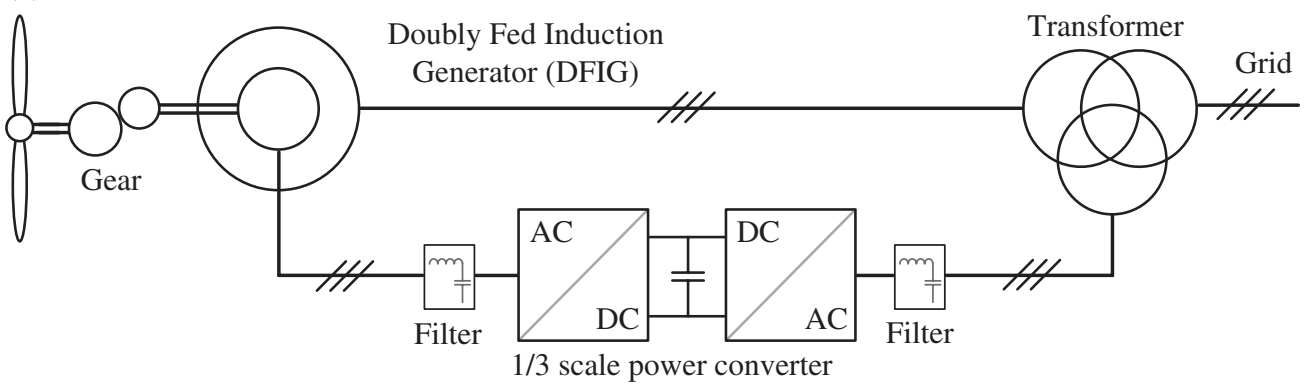

Figure 1.5 Wind power generation systems based on (a) induction/synchronous generator (I/SG), and (b) doubly fed induction generator (DFIG) (Source: Blaabjerg 2013 [9]. Reproduced with permission of IEEE).

in all operating conditions, various maximum power point tracking (MPPT) methods, such as hill-climbing, perturb and observe, incremental conductance, fuzzy theory, and genetic algorithms, have been developed for solar panel, wind turbine, and FC [11, 12], which are fulfilled by back-end power conversion devices. Appropriate energy management for energy sources, energy storage batteries, and grids has been explored for smoothing the power integrated into utility grids, which is also achieved by the power electronics-based conditioning units $[13,14]$. Therefore, the efficiency of the whole power generation system finally depends on the inverters/converters used.

\subsubsection{Existing Power Converter Topologies}

Converters are widely used in industry for performing energy conversion from one form to another [15-19]. Typical examples are adjustable speed motor drives, electric power interfaces, uninterruptible power supplies, rectifiers, and power factor correctors. Traditionally, these applications use a two-level voltage-source converter, but as the power and switching ranges increase, the two-level topology is increasingly viewed as inappropriate. The main restriction is related to the semiconductor manufacturing technology: current power devices have limited voltage rating, current rating, and switching frequency. In addition, there is currently no immediately available low-cost solution for mass-producing devices made from silicon carbide $(\mathrm{SiC})$ or gallium nitride $(\mathrm{GaN})$, even though there are some promising developments. Therefore, instead of waiting for a breakthrough in semiconductor technology, a more effective and immediate approach for resolving present restrictions is to use multilevel 
(a)

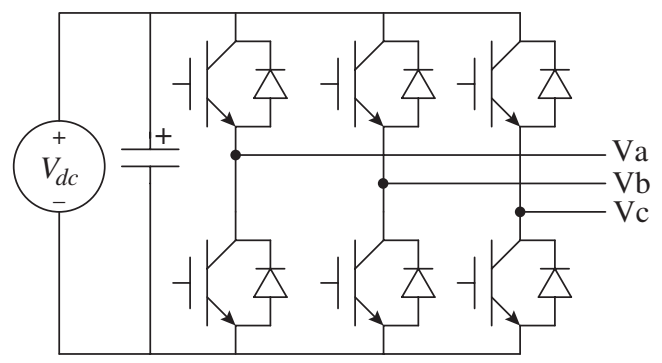

(b)

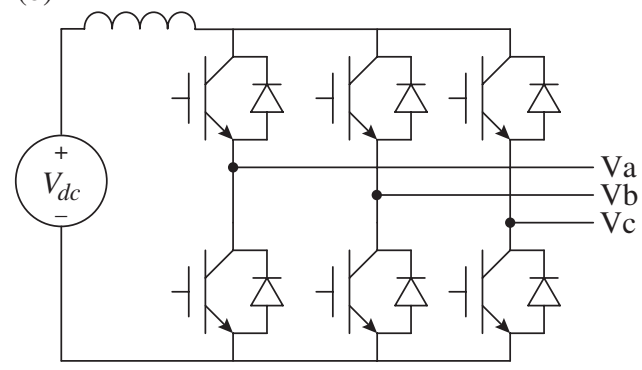

Figure 1.6 Typical dc-ac (a) voltage-source and (b) current-source converters.

converters. The advantages of multilevel converters include their well-recognized suitability for high power applications, improved harmonic performance, reduced electromagnetic interference (EMI), and a larger pool of discrete voltage levels for flexibly synthesizing the desired output voltage waveform. Multilevel converters are therefore important to the power electronic community, and will hence be reviewed briefly after introducing the basic two-level converters that have been in existence for several decades $[18,19]$.

Traditionally, two-level converters can be implemented as either a voltage-source (VS) or a current-source (CS) converter. Their representative topologies are given in Figure 1.6(a) and (b), configured for dc-ac inversion. The same topologies can be used for ac-dc rectification, but for convenience of the description, the dc-ac inversion mode is usually assumed. Beginning with the VS converter shown in Figure 1.6(a), it is fed from a dc voltage source usually filtered by a relatively large capacitor connected in parallel. For dc-to-ac conversion, a dc voltage source feeds the main converter circuit - a three-phase inverter bridge that converts the dc power to ac for an ac load. The dc voltage source is usually a dc capacitor fed by a battery, fuel cell stack, or diode rectifier. For ac-to-dc conversion, an ac source feeds the converter bridge which converts ac to dc for a dc load. Six switches are used in the main circuit, each traditionally composed of a power transistor and an anti-parallel (or free-wheeling) diode to provide bidirectional current flow and unidirectional voltage blocking. Its maximum linear ac output voltage is known to be limited to 1.15 times half the dc source voltage if triplen offsets are included for modulation $[14,15]$. The VS converter is therefore a buck or step-down dc-ac converter (or boost or step-up ac-dc converter) if no additional dc-dc converter is used for boosting its dc-link voltage.

By contrast, a CS converter is fed from a dc current source, which in most cases is implemented by connecting a dc voltage source in series with a comparably large inductor, as shown in Figure 1.6(b). The dc inductor to some extent behaves as a boosting component, whose presence allows the ac output voltage of the CS converter to be always greater than the dc source voltage. For dc-to-ac conversion, a dc current source feeds the main converter circuit - a three-phase inverter bridge that converts dc to ac, to power an ac load. The dc current source is usually a relatively large dc inductor fed by a voltage source such as a battery, fuel cell stack, diode rectifier, or thyristor converter. For ac-to-dc conversion, an ac source feeds the main converter bridge which converts ac to dc to power a dc load. Six switches are used in the main circuit, each traditionally composed of a semiconductor switching device with reverse block capability such as gate-turn-off thyristor (GTO), silicon controlled rectifier (SCR), or a 
power transistor with a series diode to provide unidirectional current flow and bidirectional voltage blocking. The CS converter is therefore only suitable for boost dc-ac power conversion (or buck ac-dc power rectification).

The VS and CS converters are thus capable of performing different types of power conversions, and should therefore be chosen based on the requirements under consideration. However, for certain well-accepted reasons such as the absence of large dc inductors and fewer semiconductors conducting in series, the VS converter has dominated most applications. This happens even though the desired system requirements might theoretically favor the CS converter more than the VS converter. This is true, for example, in photovoltaic generation, which usually demands a dc-ac boost, and the direct application of the CS converter is still not popular even though the dc-ac boost ability is inherently found with the CS converter. Instead, the VS converter is almost always adopted, even though an additional dc-dc boost converter might at times be needed. The VS converter is therefore the clear "winner." Many converters developed subsequently have adopted the same VS characteristics, including the multilevel converters to be described next.

Among the multilevel converters proposed, the three gaining most attention are the diode-clamped, cascaded, and flying-capacitor converters. The diode-clamped converter's implementation is realized by connecting multiple switches in series, and then adding clamping diodes for distributing the dc voltage stress evenly among the switches per phase-leg. For illustration, a three-level and a five-level diode-clamped converter are shown in Figure 1.7(a) and (b), respectively. The former is also referred to as the neutral-point-clamped (NPC) converter, whose dc-link voltage has been divided by capacitors $C_{1}$ and $C_{2}$ to form three distinct voltage levels, to which each phase output can be tied. For example, by turning on only switches SA1 and SA2 of the leftmost phase-leg in Figure 1.7-(a), the phase output will be tied to $+V_{d c} / 2$. Similarly, by turning on SA2 and $\mathrm{SA}^{\prime} 1$, the output will be zero, while turning on $\mathrm{SA}^{\prime} 1$ and $\mathrm{SA}^{\prime} 2$ causes the output to be $-V_{d c} / 2$. A three-level phase voltage waveform is thus produced by the four switches per phase-leg operating as two complementary pairs. The first pair consists of SA1 and SA'1, while the second pair consists of SA2 and SA'2.

The same switching principles apply to the five-level diode-clamped converter, as shown in Figure 1.7-(b), which will therefore not be explicitly described. Instead, to demonstrate its operation, Table 1.1 has been included to show how the five discrete voltage levels per phaseleg can be obtained by switching its eight switches. The diode-clamped converter is thus an ideally feasible topology, but when implemented physically, it will face a tough dc capacitor voltage balancing problem. This problem, if not resolved satisfactorily, will give rise to low-order harmonic distortion and increased voltage stress across the capacitors and semiconductor switches. Although a number of voltage balancing techniques have since been proposed with most relying on extra hardware or redundant state swapping, the balancing concern has limited a practical diode-clamped converter to only three discrete voltage levels which, as mentioned, is called the NPC converter.

For higher level converters, the cascaded multilevel inverter is preferred, and is simply assembled by connecting multiple single-phase full-bridges or H-bridges in series. A typical cascaded five-level inverter is shown in Figure 1.8, where each $\mathrm{H}$-bridge is powered by a separate dc source. Since each H-bridge generates three distinct voltage levels, $+V_{d c}, 0$, and $-V_{d c}$, the cascading of two H-bridges in series per phase-leg produces five distinct voltage levels, $+2 V_{d c},+V_{d c}, 0,-V_{d c}$, and $-2 V_{d c}$. Although the cascaded converter offers many advantages, its requirement for multiple isolated dc sources makes it an expensive topology used only for 
(a)

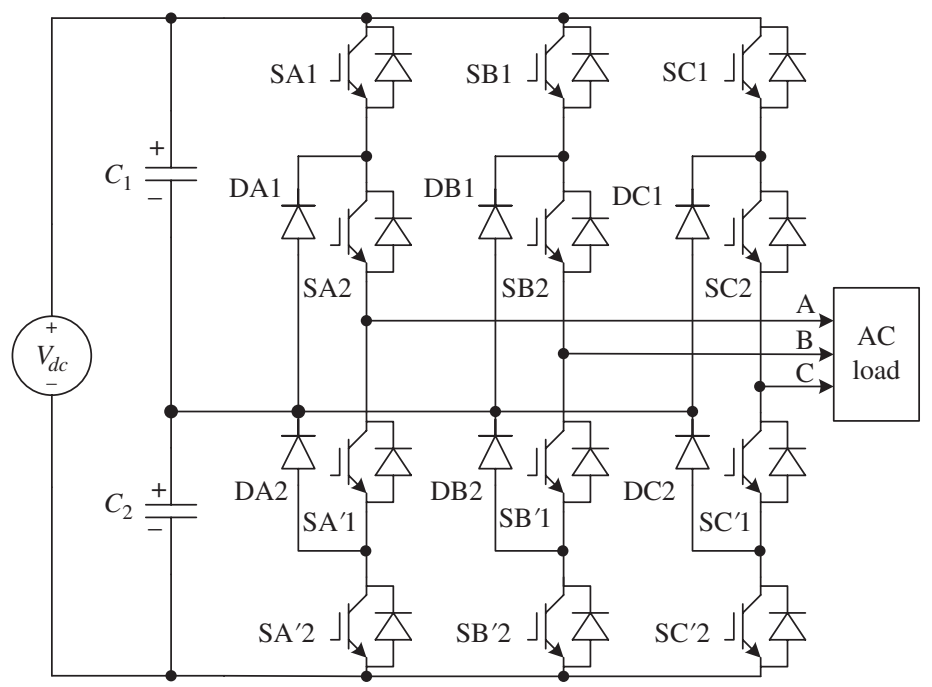

(b)

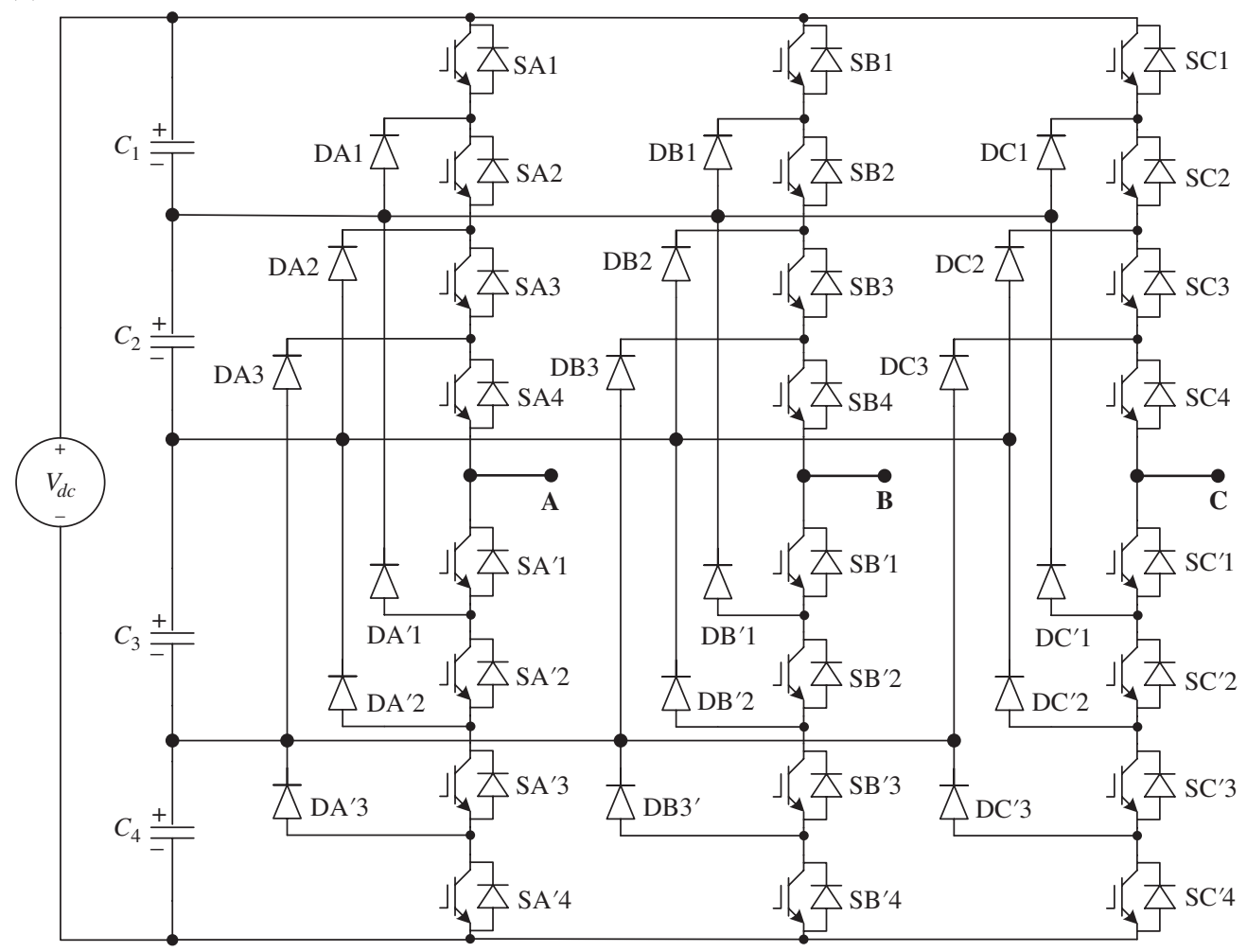

Figure 1.7 Illustrations of (a) three-level and (b) five-level diode-clamped converters. 
Table 1.1 Switching states of five-level diode-clamped converter per phase-leg $(\mathrm{X}=\mathrm{A}, \mathrm{B}$ or $\mathrm{C})$

\begin{tabular}{ll}
\hline ON Switches & Voltage \\
\hline $\mathrm{SX} 1, \mathrm{SX} 2, \mathrm{SX} 3, \mathrm{SX} 4$ & $+V_{d c} / 2$ \\
$\mathrm{SX} 2, \mathrm{SX} 3, \mathrm{SX} 4, \mathrm{SX}^{\prime} 1$ & $+V_{d c} / 4$ \\
$\mathrm{SX} 3, \mathrm{SX} 4, \mathrm{SX}^{\prime} 1, \mathrm{SX}^{\prime} 2$ & 0 \\
$\mathrm{SX} 4, \mathrm{SX}^{\prime} 1, \mathrm{SX}^{\prime} 2, \mathrm{SX}^{\prime} 3$ & $-V_{d c} / 4$ \\
$\mathrm{SX}^{\prime} 1, \mathrm{SX}^{\prime} 2, \mathrm{SX}^{\prime} 3, \mathrm{SX}^{\prime} 4$ & $-V_{d c} / 2$ \\
\hline
\end{tabular}

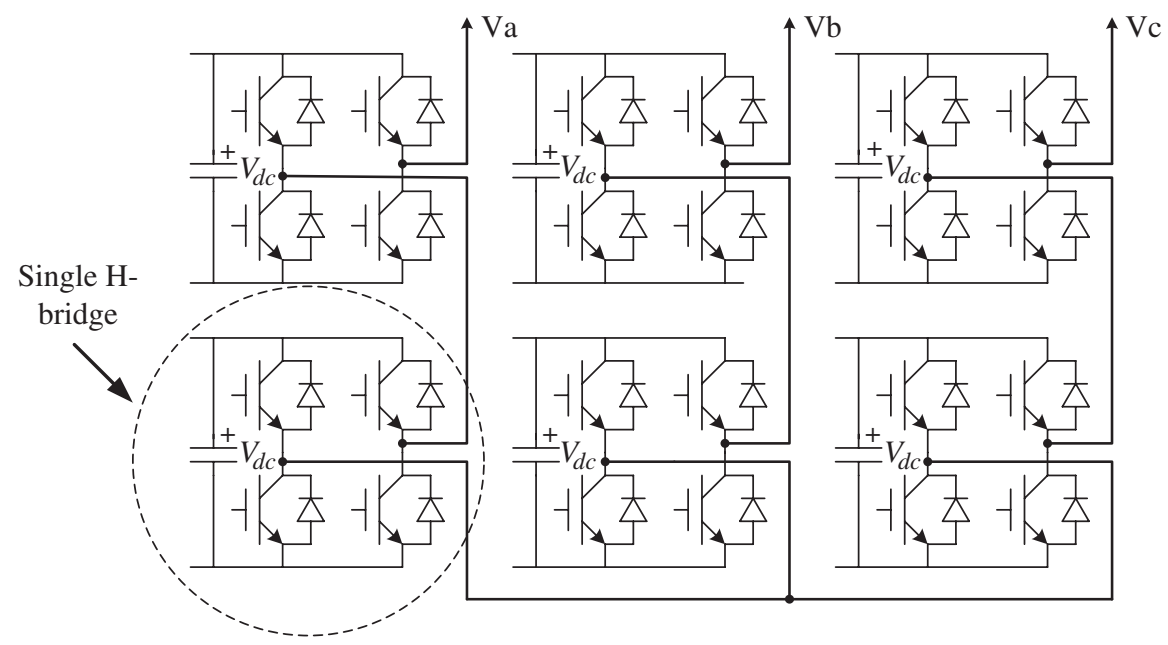

Figure 1.8 Five-level cascaded multilevel inverter [20].

converters with more than five distinct voltage levels. However, this limitation is slowly being diluted by the introduction of renewable sources, where multiple sources are readily available. Upon solving the source availability, the modular structure of the cascaded converter will again appear as an attractive feature since it allows easier converter construction and a more streamlined manufacturing process.

The third popular multilevel converter is the flying-capacitor converter, whose representative three-level phase-leg is shown in Figure 1.9. With its isolated capacitor $C_{1}$ regulated at half the dc-link voltage, the converter can produce three distinct output voltage levels: $V_{d c} / 2,0$, and $-V_{d c} / 2$. Supposing that the voltage rating of the capacitors used is the same as that of the active semiconductor switches, an $n$-level flying-capacitor converter can be realized with $(n-1) \times(n-2) / 2$ clamping capacitors per phase-leg, in addition to $(n-1)$ dc-link capacitors. That is obviously a drawback since the system size will increase tremendously with the number of output voltage levels. The increase will, however, create fewer technical problems than the diode-clamped topology because with an appropriate phase-shifted modulation scheme implemented, the capacitor voltages of the flying-capacitor converter are naturally self-balanced. A higher level flying-capacitor converter can therefore be implemented more easily, but it is unlikely to surpass the cascaded multilevel converter. 


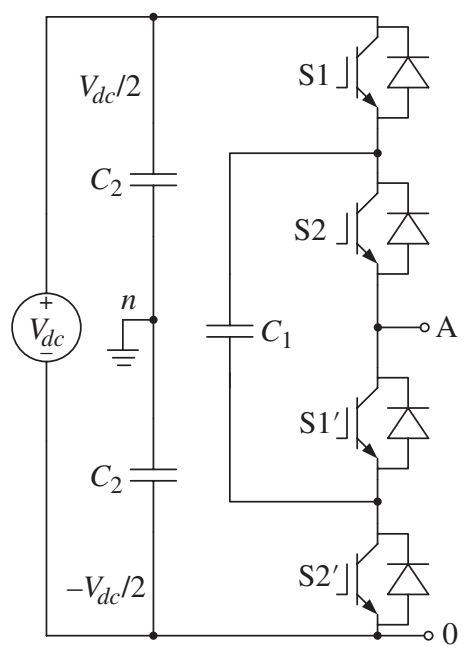

Figure 1.9 Three-level flying-capacitor converter.

\subsection{Z-Source Converter as Single-Stage Power Conversion System}

In applications that need to boost the voltage, the Z-source converter is a possibility.

The Z-source power converter was initially presented in 2002 [20]. It is an impedance source converter and it is different from conventional voltage source and current source converters. The main feature is that the impedance network consists of inductors, capacitors, and switches/diodes, and it is employed in the circuit to boost or buck the voltage. It is a circuit to combine the dc-dc boost converter and inverter, using a single-stage power conversion system. Figure 1.10 shows the general topology of the Z-source converter. A two-port network that consists of inductors $L_{1}$ and $L_{2}$ and capacitors $C_{1}$ and $C_{2}$ connected in an X shape is employed to provide an impedance source (Z-source) coupling the converter (or inverter) to the dc source or load.

A three-phase voltage-fed Z-source inverter, as shown in Figure 1.11. is used as an example to briefly illustrate the operating principle. The traditional three-phase voltagesource inverter has six active states and two zero states. For the Z-source inverter, several extra zero states are possible by gating on both the upper and lower devices of any one phase leg, any two phase legs, or all three phase legs [20]. These shoot-through zero states are forbidden in the traditional voltage-source inverter, because they would cause a short-circuit across the source. The Z-source network and shoot-through zero states provide a unique buck-boost feature of the inverter. All the traditional pulse width modulation (PWM) schemes can be used to control the Z-source inverter and their theoretical input-output relationships still hold true. In addition, with the unique feature of the shoot-through zero states, several new PWM methods: simple boost control, maximum boost control, maximum constant boost control, and space vector modulation, have been developed [20-29]. 


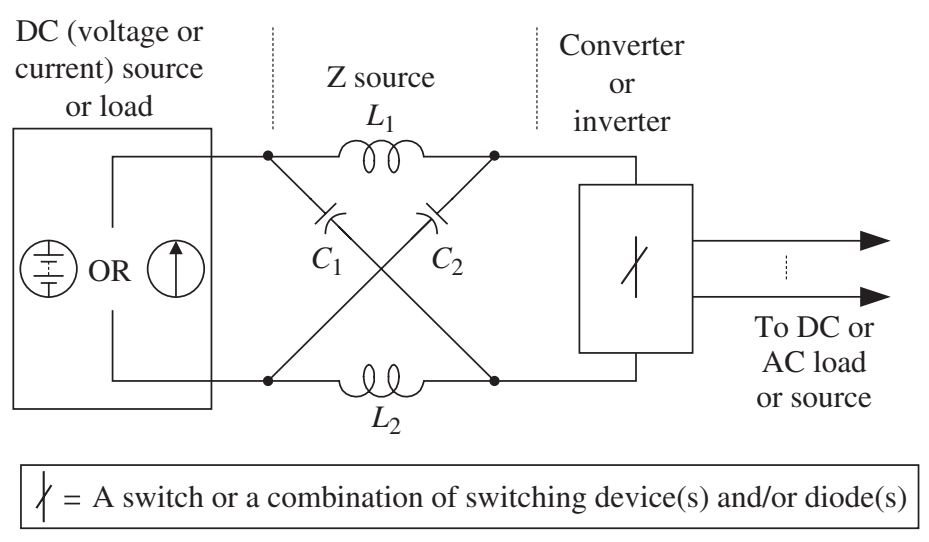

Figure 1.10 A general topology of the Z-source converter (Source: Peng 2003 [20]. Reproduced with permission of IEEE).

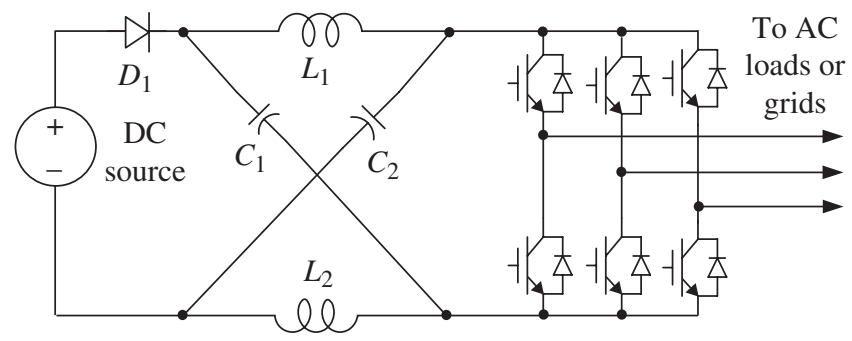

Figure 1.11 Three-phase voltage-fed Z-source inverter—an example of Z-source inverter.

\subsection{Background and Advantages Compared to Existing Technology}

As mentioned before, power electronics is the enabling technology for the energy processing necessary for electronic and electrical equipment of all types, from renewable energy to power systems, from house appliances to aerospace systems. Both the VS converter and CS converter have their conceptual and theoretical limitations and barriers that prevent economical and efficient solutions to many applications.

The VS converter has the following three conceptual and theoretical limitations:

1. The ac load has to be inductive or the ac source has to have series inductors.

2. The ac output voltage has an upper limit because it cannot exceed the dc rail voltage or the dc rail voltage has to be greater than the ac input voltage. Therefore, the VS inverter is a buck (i.e. step-down) inverter for dc-to-ac power conversion and the VS converter is a boost (i.e. step-up) rectifier (or boost converter) for ac-to-dc power conversion. For dc-to-ac power conversion applications where the dc voltage is given, the obtainable maximum ac output can not be greater than the given dc voltage. For ac-to-dc power conversion applications, where the ac source voltage is fixed, the minimum dc output is limited because it can 
not be lower than the ac peak voltage. These output voltage limitations are major barriers to reducing the system cost and increasing the conversion efficiency, because another stage of dc-dc boost or buck conversion is required for many applications that need wide output voltage ranges.

3. The upper and lower devices of each phase leg cannot be gated on simultaneously either on purpose or by EMI noise. Otherwise, a shoot-through would occur and destroy the devices. The shoot-through problem caused by misgating due to EMI noise is the major threat to the converter's reliability.

The CS converter has the following four conceptual and theoretical barriers and limitations:

1. The ac side has to be capacitive or has to have parallel capacitors for the CS converter to operate.

2. The ac output voltage has to be greater than the original dc voltage that feeds the dc inductor or the dc voltage produced is always smaller than the ac input voltage. Therefore, the CS inverter is a boost inverter for dc-to-ac power conversion and the CS converter is a buck rectifier (or buck converter) for ac-to-dc power conversion. For applications where a wide voltage range is required, an additional dc-to-dc buck (or boost) converter is needed. This additional power conversion stage again increases system cost and lowers the conversion efficiency.

3. At least one of the upper devices and one of the lower devices have to be gated on and maintained on at any time. Otherwise, an open circuit of the dc inductor would occur and this will destroy the devices. The open-circuit problem of EMI noise causing misgating off is a threat to the converter's reliability.

4. The main switches of the CS converter have to block any reverse voltage which requires a series diode to be used in combination with high-speed and high-performance transistors such as insulated gate bipolar transistors (IGBTs). This prevents the direct use of low-cost and high-performance IGBT modules and integrated power modules (IPMs).

In summary, both the VS converter and the CS converter have the following three common problems:

1. They are either a boost or a buck converter and cannot be a buck-boost converter. Hence, their obtainable output voltage range is limited to either lower or higher than the input voltage.

2. Their main circuits cannot be interchangeable. In other words, the main circuit of the VS converter can not be used as a CS converter and vice versa.

3. They are vulnerable to EMI noise and thus are not as reliable as desired.

The Z-source power converter provides a new single-stage converter topology and theory with the intention of achieving the functions of two-stage power converters. The Z-source converter compromises an impedance network to couple the main converter circuit to the power source or load. As a result, the Z-source converter is neither a VS converter nor a CS converter and has none of their inherent problems.

The major unique feature of the Z-source network is that, unlike the traditional VS or CS, it can be open- and short-circuited, which provides a mechanism for the main converter circuit 
to step up or step down the voltage as desired. The Z-source network provides the following three aspects of flexibility for the source, main circuit, and load:

1. The source of the Z-source converter can be either a voltage source or a current source. Therefore, unlike the traditional VS or CS converters, the Z-source converter's dc source can be anything, such as a battery, a diode rectifier, a thyristor converter, a fuel cell stack, an inductor, a capacitor, or a combination of these.

2. The main circuit of the Z-source converter can be either a traditional VS configuration or a traditional CS configuration. In addition, switches used in the Z-source converter can be a combination of switching devices and diodes such as the anti-parallel combination shown in Figure 1.6-(a) or the series combination shown in Figure 1.6 (b).

3. The load of the Z-source converter can be inductive or capacitive.

\subsection{Classification and Current Status}

As shown in Figure 1.10, a two-port network that consists of inductors $L_{1}$ and $L_{2}$ and capacitors $C_{1}$ and $C_{2}$ connected in a unique $\mathrm{X}$ shape is employed to provide an impedance source (Z-source) coupling the converter (or inverter) to the dc source or load. The unique feature of the Z-source network is that, unlike the traditional VS or CS, it can be open- or short-circuited, which provides a mechanism for the main converter circuit to step up and step down voltage as desired in a single-stage power conversion. These features give the Z-source converter not only a high reliability against EMI, but also fewer components and lower cost to achieve the same function as a conventional two-stage converter/inverter (dc-dc converter plus inverter). The configuration allows the elimination of dead time, which improves the output current/ voltage waveform quality (no distortion). The Z-source concept has been extended to all dc-to-ac, ac-to-dc, ac-to-ac, and dc-to-dc converter power conversions [30, 31].

The involved application fields include PV power generation [32-38], wind power generation [39-46], electric vehicles [47-51], etc. Without doubt, the Z-source converter has been a significant branch of power electronic converters, following on from VS and CS converters.

Z-source related research has been a hot topic since its birth. The number of modifications and new Z-source topologies has exploded. Figure 1.12-(a) and (b) shows a summary of the Z-source converter categories and Z-source network topologies that can be found in recent literature, with the chapter numbers for this book. They can be sorted into four main categories according to conversion functionality: ac-dc rectifiers, dc-ac inverters, ac-ac converters, and dc-dc converters. A further breakdown leads to two-level and multilevel [20-29, 32-38], ac-ac regulators [52-56], matrix converters [57-63], and non-isolated and isolated dc-dc converters [64-68]. From the Z-source network topology standpoint, it can be voltage-fed or current-fed. The Z-source networks can be divided into four types: original Z-source [20], quasi Z-source [69], trans-Z-source [70], and other Z-source, such as embedded Z-source, semi-Z-source, distributed Z-network, switched inductor Z-source, tapped-inductor Z-source, and diodeassisted and capacitor-assisted quasi-Z-source, LCCT-Z-source [71-75]. All are derived from the original Z-source and quasi-Z-source topologies.

All the diverse Z-source network topologies in the literature have been derived by modifying the original Z-source network, or by rearranging the connections of inductors and capacitors. Each Z-source network topology has its unique features for different or particular application needs. 
(a)

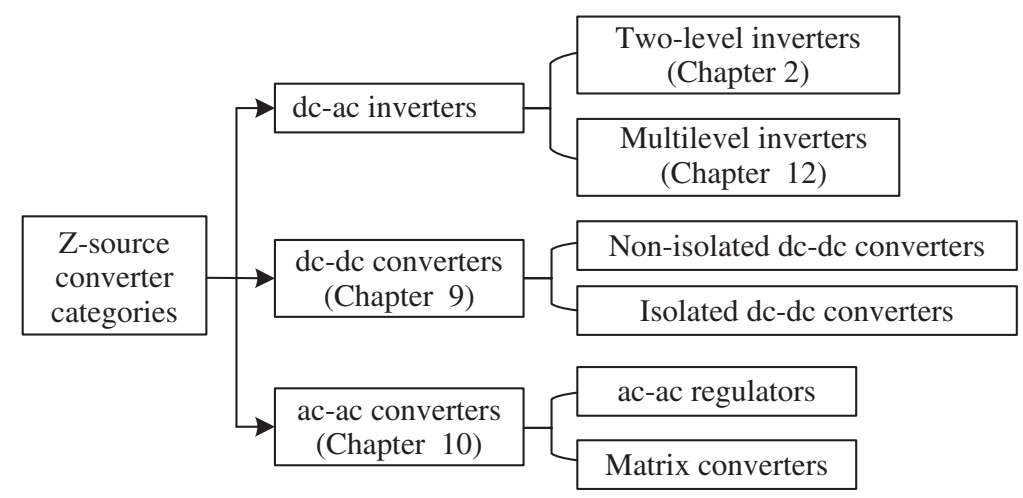

(b)

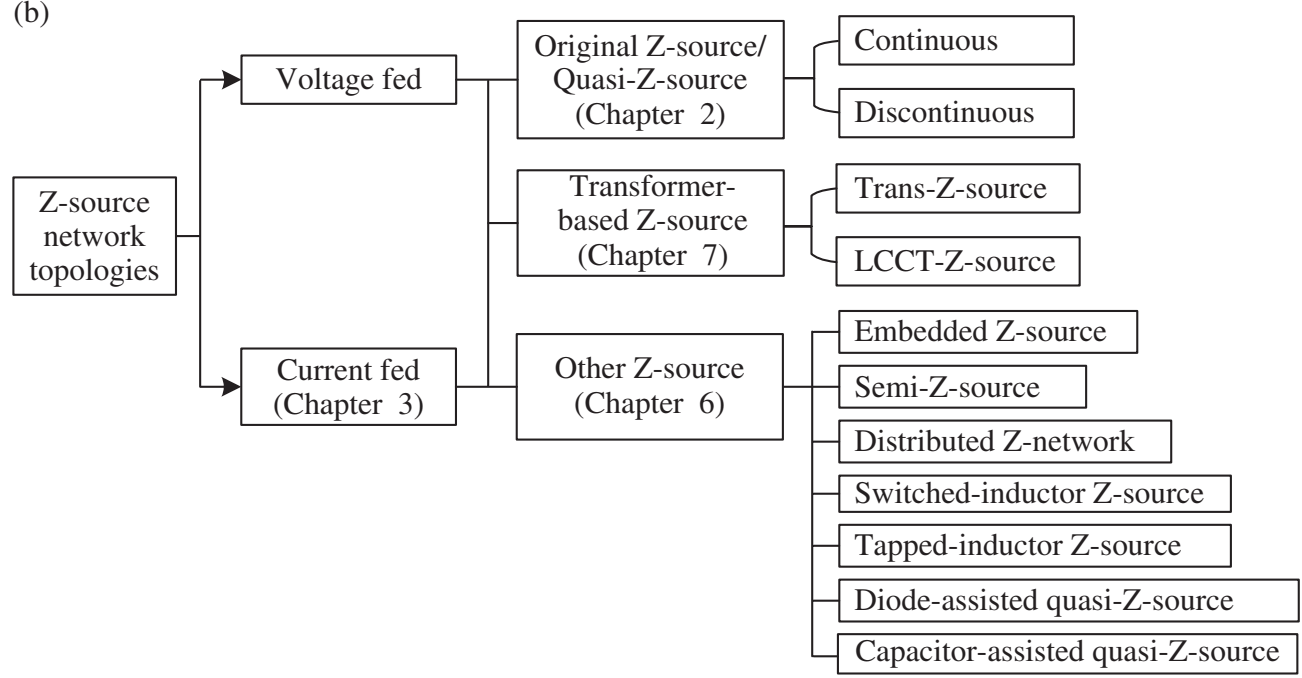

Figure 1.12 Summary of different $Z$-source converters in the literature, plus chapter numbers for this book: (a) Z-source converter categories; (b) Z-source network topologies.

New Z-source topologies are still being developed for three main reasons: (1) reduction of the Z-source network component count and rating, (2) extension of voltage gain range, and (3) application-oriented optimization and improvement.

For example, four quasi-Z-source (two voltage-fed and two current-fed) inverters were proposed to reduce the passive component ratings, to achieve continuous input current, and to provide a common negative dc rail between the source and inverter bridge. These new benefits spread this topology to applications of renewable energy generation and motor drives. The embedded Z-source was proposed to achieve continuous input current and lower capacitor voltage rating, and its multi-source feature is suitable for photovoltaic power generation. Theoretically, the original Z-source, quasi-Z-source, and embedded Z-source, all have unlimited voltage gain. However, a high voltage gain $(>2-3)$, will result in a high voltage stress imposed on the switches. Trans-Z-source (two voltage-fed and two current-fed) inverters were proposed to have higher voltage gains while keeping voltage stress low and reducing component 
count to one transformer (or one coupled inductor) and one capacitor. There are many other ways to increase voltage gain by integrating traditional switched-inductor, switchedcapacitor, tapped-inductor, diode-assisted, and capacitor-assisted extensions to the Z-source/ quasi-Z-source network, but they require more components. Semi-Z-source inverters were proposed to achieve low cost and high efficiency in applications such as single-phase grid-tie PV power systems. A semi-Z-source inverter with only two active switches has a voltage boost function and a double-ground feature that eliminates the need to float/isolate PV panels without leakage current, and improves safety. Distributed impedance networks such as transmission lines and hybrid LC components can be used for a Z-source network. These distributed Z-source networks are difficult to implement, but, a distributed Z-source inverter does not need any extra diode or switch to achieve the voltage boost function, thus having minimum component count.

\subsection{Future Trends}

Obviously, the Z-source concept has opened up a new research area in the power electronics field. The above description only provides a brief summary of the major Z-source network topologies. There are many modifications and twists of the Z-source topologies mentioned. Each topology has its own unique features and suited applications. There is no one-size-fits-all solution. It is feasible that new Z-source topologies will continue to appear to meet needs and improve performance in different applications. Motor drives and renewable energy generation, such as PV and wind power, will be perspective applications for Z-source converters, because of the unique voltage buck-boost ability with minimum component count and potential low cost. New power electronic devices, such as the $\mathrm{SiC}$ and $\mathrm{GaN}$, will definitely improve the Z-source converters' performance. Their high switching frequency, low loss, and high temperature capacity will contribute to smaller size Z-source passive components and high converter efficiency. Z-source converters are still driving forward in terms of topologies and applications. Chapter 20 will provide detailed prospects.

\subsection{Contents Overview}

A brief introduction of the concept, advantages, classification, current status, and future trends have been reviewed in this chapter, and detailed system contents are presented throughout the rest of this book. As illustrated in Figure 1.12, Chapters 2 and 3 provide comprehensive analysis of the operating principle and modeling of voltage-fed and current-fed Z-source/quasiZ-source inverters (ZSI/qZSI); different modulation methods and shoot-through duty cycle control methods are discussed in Chapters 4 and 5; an overview of various improved Z-source/ quasi-Z-source (ZS/qZS) networks is addressed in Chapter 6; typical extended converter topologies, such as transformer-based Trans-ZSI/qZSI and LCCT-ZSI/qZSI, ZS/qZS ac-dc rectifiers, Z-source dc-dc converters, ZS/qZS matrix converters, energy stored ZSI/qZSI, and ZS/qZS multilevel inverters are detailed in Chapters 7-12, including their principle, modeling, control, and examples; hardware design, especially the impedance value design, is demonstrated in Chapter 13; their applications to PV and wind generation systems, adjustable speed drives, and multi-leg (four-leg and five-phase) converters/inverters are described in Chapters 14-17; the model predictive control (MPC) of ZSI/qZSI is illustrated in Chapter 18; 
grid integration of the qZS-based PV multilevel inverter is discussed for the traditional method and MPC in Chapter 19; finally, Chapter 20 presents future prospects of this promising topology.

\section{Acknowledgment}

Most of this chapter (except Subsection 1.1.2) was made possible by NPRP-EP grant \# [X-033-2-007] from the Qatar National Research Fund (a member of Qatar Foundation). The statements made herein are solely the responsibility of the authors.

\section{References}

[1] D. M. Tagare, Electricity Power Generation: The Changing Dimensions, Wiley \& Sons Ltd, 2011.

[2] REN21 (2014, June). The First Decade (2004-2014), 10 Years of Renewable Energy Progress. [Online]. Available: http://www.ren21.netPortals/0/documents/activities/Topical\%20Reports/REN21_10yr.pdf.

[3] Wikipedia, Wind power. [Online]. Available: https://en.wikipedia.org/wiki/Wind_power\#cite_note-GWEC_ Market-1.

[4] IEA PVPS International Energy Agency Photovoltaic Power Systems Programme (2015, March). IEA PVPS Report: 2014 Snapshot of Global PV Markets. [Online]. Available: http://www.iea-pvps.org/fileadmin/dam/ public/report/technical/PVPS_report_-_A_Snapshot_of_Global_PV_-_1992-2014.pdf.

[5] W. Vielstich, Handbook of Fuel Cells, John Wiley \& Sons Ltd, 2009.

[6] H. Abu-Rub, M. Malinowski, K. Al-Haddad, Power Electronics for Renewable Energy Systems, Transportation and Industrial Applications. John Wiley \& Sons, 2014.

[7] F. Blaabjerg, Z. Chen, S. B. Kjaer, "Power electronics as efficient interface in dispersed power generation systems," IEEE Trans. Power Electron., vol.19, no.4, pp.1184-1194, 2004.

[8] S. B. Kjaer, J. K. Pedersen, F. Blaabjerg, "A review of single-phase grid-connected inverters for photovoltaic modules,” IEEE Trans. Ind. Appl., vol.41, no.5, pp.1292-1306, Sep. 2005.

[9] F. Blaabjerg, M. Ke, "Future on power electronics for wind turbine systems," IEEE Journal of Emerging and Selected Topics in Power Electronics, vol.1, no.3, pp.139-152, Sept. 2013.

[10] M. Liserre, R. Cardenas, M. Molinas, J. Rodriguez, "Overview of Multi-MW wind turbines and wind parks," IEEE Trans. Ind. Electron., vol.58, no.4, pp.1081-1095, April 2011.

[11] M. A. Khattak, M. Asif Khattak, A Review \& Analysis of Solar MPPT Algorithms \& Hardware Architectures. LAP LAMBERT Academic Publishing, 2014.

[12] M. A. G. de Brito, L. Galotto, L. P. Sampaio, G. de Azevedo e Melo, C. A. Canesin, "Evaluation of the main MPPT techniques for photovoltaic applications," IEEE Trans. Ind. Electron., vol.60, no.3, pp.1156-1167, March 2013.

[13] D. A. Howey, S. M. Mahdi Alavi, Rechargeable Battery Energy Storage System Design. John Wiley \& Sons, 2015.

[14] Y. Brunet, Energy Storage, John Wiley \& Sons, 2010.

[15] K. Thorborg, Power Electronics, Prentice Hall International (UK) Ltd., London, 1988.

[16] M. H. Rashid, Power Electronics, 2nd Edition, Prentice Hall, 1993.

[17] N. Mohan, W. P. Robbin, T. Undeland, Power Electronics: Converters, Applications, and Design, 2nd Edition, John Wiley and Sons, 1995.

[18] A. M. Trzynadlowski, Introduction to Modern Power Electronics, John Wiley and Sons, 1998.

[19] B. K. Bose, Modern Power Electronics and AC Drives, Prentice Hall PTR, 2002.

[20] F. Z. Peng, “Z-Source Inverter," IEEE Trans. Ind. Appl., vol.39, no.2, pp.504-510, March/April 2003. The paper was originally presented at the 2002 IEEE/IAS Annual Meeting.

[21] F. Z. Peng, M. Shen, Z. Qian, "Maximum boost control of the Z-source inverter," IEEE Trans. Power Electron., vol.20, no.4, pp.833-838, July 2005.

[22] M. Shen, J. Wang, A. Joseph, F. Z. Peng, Tolbert L. M., Adams D. J., "Constant boost control of the Z-source inverter to minimize current ripple and voltage stress," IEEE Trans. Ind. Appl., vol.42, no.3, pp.770-778, May-Jun 2006. 
[23] Y. Liu, B. Ge, F. J. T. E. Ferreira, A. T. de Almeida, H. Abu-Rub, "Modeling and SVM control of quasi-Z-source inverter," in Proc. 11th International Conference on Electrical Power Quality and Utilisation (EPQU), 2011, pp.1-7.

[24] Y. Tang, S. Xie, J. Ding, "Pulse-width Modulation of Z-Source Inverters With Minimum Inductor Current Ripple," IEEE Trans. Ind. Electron., vol.61, pp.98-106, 2014.

[25] J. Jung, A. Keyhani, "Control of a fuel cell based Z-source converter," IEEE Trans. Energy Convers., vol.22, no.2, pp.467-476, June 2007.

[26] U. S. Ali, V. Kamaraj, "A novel space vector PWM for Z-source inverter," in Proc. 2011 1st International Conference on Electrical Energy Systems (ICEES), 2011, pp.82-85.

[27] H. Rostami, D. A. Khaburi, "Voltage gain comparison of different control methods of the Z-source inverter," in Proc. International Conference on Electrical and Electronics Engineering (ELECO), 2009, pp.I-268-I-272.

[28] O. Ellabban, J. Van Mierlo, P. Lataire, "Experimental study of the shoot-through boost control methods for the Z-source inverter," European Power Electronics and Drives Association Journal, vol.21, no.2, pp.18-29, June 2011.

[29] Y. Liu, B. Ge, H. Abu-Rub, F. Z. Peng, "Overview of Space Vector Modulations for Three-phase Z-Source/ Quasi-Z-Source Inverters," IEEE Trans. Power Electron., vol.29, no.4, pp.2098-2108, April 2014.

[30] Y. Liu, H. Abu-Rub, B. Ge, “Z-Source/Quasi-Z-Source Inverters - Derived Networks, Modulations, Controls, and Emerging Applications to Photovoltaic Conversion," IEEE Ind. Electron. Mag., vol.8, no.4, pp.32-44, Dec. 2014.

[31] Y. P. Siwakoti, F. Z. Peng, F. Blaabjerg, P. C. Loh, G. E. Town, "Impedance-Source Networks for Electric Power Conversion Part I: A Topological Review," IEEE Trans. Power Electron., vol.30, no.2, pp.699-716, Feb. 2015.

[32] L. Liu, H. Li, Y. Zhao, X. He, Z. J. Shen, "1 MHz cascaded Z-source inverters for scalable grid-interactive photovoltaic (PV) applications using GaN device," in Proc. 2011 IEEE Energy Conversion Congress and Exposition (ECCE), pp.2738-2745, 2011.

[33] Y. Zhou, L. Liu, H. Li, "A High-Performance Photovoltaic Module-Integrated Converter (MIC) Based on Cascaded Quasi-Z-Source Inverters (qZSI) Using eGaN FETs," IEEE Trans. Power Electron., vol.28, no.6, pp.2727-2738, June 2013.

[34] D. Sun, B. Ge, F. Z. Peng, H. Abu-Rub, D. Bi, Y. Liu, "A New Grid-Connected PV System Based on Cascaded H-bridge Quasi-Z Source Inverter," in Proc. 2012 IEEE International Symposium on Industrial Electronics (ISIE), pp.951-956, 2012.

[35] Y. Fayyad, L. Ben-Brahim, "Multilevel cascaded Z source inverter for PV power generation system," in Proc. 2012 International Conference on Renewable Energy Research and Applications (ICRERA), pp.1-6, 2012.

[36] Y. Liu, B. Ge, H. Abu-Rub, F. Z. Peng, "A Modular Multilevel Space Vector Modulation for Photovoltaic Quasi-Z-Source Cascade Multilevel Inverters”, in Proc. 2013 Twenty-Eighth Annual IEEE Applied Power Electronics Conference and Exposition (APEC), pp.714-718, 2013.

[37] Y. Liu, B. Ge, H. Abu-Rub, F. Z. Peng, "An Effective Control Method for Quasi-Z-Source Cascade Multilevel Inverter-based Grid-tie Single-Phase Photovoltaic Power System”, IEEE Trans. Ind. Informat., vol.10, no.1, pp.399-407, Feb. 2014.

[38] Y. Xue, B. Ge, F. Z. Peng, "Reliability, Efficiency, and Cost Comparisons of MW Scale Photovoltaic Inverters," in Proc. IEEE Energy Conversion Congress and Exposition (ECCE), pp.1627-1634, 2012.

[39] S. Qu, W. Yongyu, "On control strategy of Z-source inverter for grid integration of direct-driven wind power generator," in 31st Chinese Control Conference (CCC), pp.6720-6723, 25-27 July 2012.

[40] X. Wang, D. M. Vilathgamuwa, K. J. Tseng, C. J. Gajanayake, "Controller design for variable-speed permanent magnet wind turbine generators interfaced with Z-source inverter," in Proc. International Conference on Power Electronics and Drive Systems (PEDS), pp.752-757, 2009.

[41] S. M. Dehghan, M. Mohamadian, A. Y. Varjani, "A New Variable-Speed Wind Energy Conversion System Using Permanent-Magnet Synchronous Generator and Z-Source Inverter," IEEE Trans. Energy Convers., vol.24, no.3, pp.714-724, Sept. 2009.

[42] U. Supatti, F. Z. Peng, "Z-source inverter with grid connected for wind power system," in Proc. 2009 IEEE Energy Conversion Congress and Exposition (ECCE), pp.398-403, 2009.

[43] T. Maity, H. Prasad, V. R. Babu, "Study of the suitability of recently proposed quasi Z-source inverter for wind power conversion," in Proc. 2014 International Conference on Renewable Energy Research and Application (ICRERA), pp.837-841, 2014.

[44] W.-T. Franke, M. Mohr, F. W. Fuchs, "Comparison of a Z-source inverter and a voltage-source inverter linked with a DC/DC-boost-converter for wind turbines concerning their efficiency and installed semiconductor power," in Proc. 2008 IEEE Power Electronics Specialists Conference (PESC), pp.1814-1820, 2008. 
[45] Y. Liu, B. Ge, F. Z. Peng, H. Abu-Rub, A. T. De Almeida, F. J. T. E. Ferreira, "Quasi-Z-Source inverter based PMSG wind power generation system," in Proc. 2011 IEEE Energy Conversion Congress and Exposition (ECCE), pp.291-297, 2011.

[46] B. K. Ramasamy, A. Palaniappan, S. M. Yakoh, "Direct-drive low-speed wind energy conversion system incorporating axial-type permanent magnet generator and Z-source inverter with sensorless maximum power point tracking controller,' IET Renewable Power Generation, vol.7, no.3, pp.284-295, May 2013.

[47] F. Z. Peng, M. Shen, K. Holland, "Application of Z-Source Inverter for Traction Drive of Fuel Cell-Battery Hybrid Electric Vehicles," IEEE Trans. Power Electron., vol.22, no.3, pp.1054-1061, May 2007.

[48] S. M. Dehghan, M. Mohamadian, A. Yazdian, "Hybrid Electric Vehicle Based on Bidirectional Z-Source NineSwitch Inverter," IEEE Trans. Veh. Commun., vol.59, no.6, pp.2641-2653, July 2010.

[49] F. Guo, L. Fu, C. Lin, C. Li, W. Choi, J. Wang, "Development of an 85-kW Bidirectional Quasi-Z-Source Inverter With DC-Link Feed-Forward Compensation for Electric Vehicle Applications," IEEE Trans. Power Electron., vol.28, no.12, pp.5477-5488, Dec. 2013.

[50] P. Liu, H. P. Liu, "Permanent-magnet synchronous motor drive system for electric vehicles using bidirectional Z-source inverter," IET Electrical Systems in Transportation, vol.2, no.4, pp.178-185, December 2012.

[51] Q. Lei, D. Cao, F. Z. Peng, "Novel Loss and Harmonic Minimized Vector Modulation for a Current-Fed Quasi-Z-Source Inverter in HEV Motor Drive Application,” IEEE Trans. Power Electron., vol.29, no.3, pp.1344-1357, March 2014.

[52] X. Fang, Z. Qian, F. Z. Peng, "Single-phase Z-source PWM AC-AC converters," IEEE Power Electron Lett., vol.3, no.4, pp.121-124, Dec. 2005.

[53] Y. Tang, S. Xie, C. Zhang, "Z-Source AC-AC Converters Solving Commutation Problem," IEEE Trans. Power Electron., vol.22, no.6, pp.2146-2154, Nov. 2007.

[54] M. Nguyen, Y. Jung, Y. Lim, "Single-Phase AC-AC Converter Based on Quasi-Z-Source Topology," IEEE Trans. Power Electron., vol.25, no.8, pp.2200-2210, Aug. 2010.

[55] L. He, S. Duan, F. Z. Peng, "Safe-Commutation Strategy for the Novel Family of Quasi-Z-Source AC-AC Converter," IEEE Trans. Ind. Informat., vol.9, no.3, pp.1538-1547, Aug. 2013.

[56] M. Nguyen, Y. Lim, Y. Kim, “A Modified Single-Phase Quasi-Z-Source AC-AC Converter," IEEE Trans. Power Electron., vol.27, no.1, pp.201-210, Jan. 2012.

[57] W. Song, Y. Zhong, H. Zhang, X. Sun, Q. Zhang, W. Wang, "A study of Z-source dual-bridge matrix converter immune to abnormal input voltage disturbance and with high voltage transfer ratio," IEEE Trans. Ind. Informat., vol.9, no.2, pp.828-838, May 2013.

[58] X. Liu, P. C. Loh, P. Wang, X. Han, "Improved modulation schemes for indirect Z-source matrix converter with sinusoidal input and output waveforms," IEEE Trans. Power Electron., vol.27, no.9, pp.4039-4050, Sept. 2012.

[59] B. Ge, Q. Lei, W. Qian, F. Z. Peng, "A family of Z-source matrix converters," IEEE Trans. Ind. Electron., vol.59, no.1, pp.35-46, Jan. 2012.

[60] S. Liu, B. Ge, H. Abu-Rub, F. Z. Peng, and Y. Liu, "Quasi-Z-source matrix converter based induction motor drives," in Proc. 38th Annual Conference on IEEE Industrial Electronics Society (IECON), pp.5303-5307, 2012.

[61] O. Ellabban, H. Abu-Rub, B. Ge, "A Quasi-Z-Source Direct Matrix Converter Feeding a Vector Controlled Induction Motor Drive," IEEE Journal of Emerging and Selected Topics in Power Electronics, vol.3, no.2, pp.339-348, June 2015.

[62] L. Huber, D. Borojevic, "Space vector modulated three-phase to three-phase matrix converter with input power factor correction,” IEEE Trans. Ind. Appl., vol.31, no.6, pp.1234-1246, Nov/Dec 1995.

[63] M. Shen, A. Joseph, J. Wang, F. Z. Peng, D. J. Adams, "Comparison of traditional inverters and Z-source inverter for fuel cell vehicles," IEEE Trans. Power Electron., vol.22, no.4, pp.1453-1463, July 2007.

[64] D. Vinnikov, I. Roasto, "Quasi-Z-Source-based isolated DC/DC converters for distributed power generation," IEEE Trans. Ind. Electron., vol.58, pp.192-201, Jan 2011.

[65] I. Roasto, D. Vinnikov, "New voltage mode control method for the quasi-Z-Source-based isolated DC/DC converters," in Proc. 2012 IEEE International Conference on Industrial Technology (ICIT), pp.644-649, 2012.

[66] A. Chub, O. Husev, D. Vinnikov, F. Blaabjerg, "Novel family of quasi-Z-source DC/DC converters derived from current-fed push-pull converters," in Proc. 2014 16th European Conference on Power Electronics and Applications (EPE'14-ECCE Europe), pp.1-10, 2014.

[67] Y. P. Siwakoti, F. Blaabjerg, P. C. Loh, G. E. Town, "High-voltage boost quasi-Z-source isolated DC/DC converter," IET Power Electronics, vol.7, no.9, pp.2387-2395, September 2014. 
[68] V. Fernão Pires, E. Romero-Cadaval, D. Vinnikov, I. Roasto, J. F. Martins, "Power converter interfaces for electrochemical energy storage systems - A review," Energy Conversion and Management, vol.86, pp.453-475, 2014.

[69] J. Anderson and F. Z. Peng, "Four quasi-Z-Source inverters," in Proc. PESC '08 - 39th IEEE Annual Power Electronics Specialists Conference, 2008, pp.2743-2749.

[70] W. Qian, F. Z. Peng, H. Cha, "Trans-Z-Source Inverters," IEEE Trans. Power Electron., vol.26, no.12, pp.3453-3463, Dec. 2011.

[71] C. J. Gajanayake, F. Luo, H. B. Gooi, P. L. So, L. K. Siow, "Extended-BoostZ-Source Inverters," IEEE Trans. Power Electron., vol.25, no.10, pp.2642-2652, Oct. 2010.

[72] M. Zhu, K. Yu, F. Luo, “Switched Inductor Z-Source Inverter," IEEE Trans. Power Electron., vol.25, no.8, pp.2150-2158, Aug. 2010.

[73] N. Minh-Khai, Y. Lim, G. Cho, "Switched-Inductor Quasi-Z-Source Inverter," IEEE Trans. Power Electron., vol.26, no.11, pp.3183-3191, Nov. 2011.

[74] M. Adamowicz, J. Guzinski, R. Strzelecki, F. Z. Peng, H. Abu-Rub, "High step-up continuous input current LCCT-Z-source inverters for fuel cells," in Proc. 2011 IEEE Energy Conversion Congress and Exposition (ECCE), pp.2276-2282, 2011.

[75] M. Adamowicz, R. Strzelecki, F. Z. Peng, J. Guzinski, H. Abu-Rub, "New type LCCT-Z-source inverters," in Proc. of 14th European Conference on Power Electronics and Applications (EPE), pp.1-10, 2011. 